\title{
Isolation and characterization of adhesin-defective TnphoA mutants of septicaemic porcine Escherichia coli of serotype $0115: \mathrm{K}^{-}: \mathrm{F} 165$
}

\author{
J. Harel, ${ }^{*}$ C. Forget, M. Ngeleka, M. Jacques and J. M. Fairbrother \\ Department of Pathology and Microbiology, Faculty of Veterinary Medicine, University of Montreal, Saint-Hyacinthe, \\ Québec, Canada J2S 7C6
}

(Received 28 January 1992; revised 8 June 1992; accepted 14 July 1992)

\begin{abstract}
Non-enterotoxigenic porcine Escherichia coli strains belonging to the serogroup 0115 have been associated with septicaemia and diarrhoea. Putative factors important in the pathogenicity of $E$. coli of serogroup $O 115$ include fimbrial antigen F165, haemagglutination (MRHA), lipopolysaccharide, serum resistance, capsule and production of aerobactin. Using TnphoA transposon insertion mutagenesis, two classes of mutants were obtained from $E$. coli of serotype 0115: F165 with respect to the phenotypic expression of fimbrial antigen F165 and MRHA of sheep erythrocytes: class I, $\mathrm{F165}^{-} \mathrm{MRHA}^{-}$, serum resistant; class II, $\mathrm{F165}^{+} \mathrm{MRHA}^{-}$, serum resistant. In a chicken lethality model, class I mutants were either virulent or of intermediate virulence, while class II mutants were of intermediate virulence. Alkaline phosphatase activity of class I and class II TnphoA mutants showed similar environmental regulation to that of fimbrial antigen F165. Moreover, class I and class II mutants were mutated in the prs-like locus, and lacked a $18.5 \mathrm{kDa}$ and $/$ or a $17.5 \mathrm{kDa}$ fimbrial band.
\end{abstract}

\section{Introduction}

Certain pathogenic Escherichia coli strains cause localized or systemic extra-intestinal diseases such as urinary tract infection, septicaemia, meningitis and polyserositis (Ørskov \& Ørskov, 1985). The virulence mechanisms of such strains appear to be complex and are only partially understood. These are thought to include the ability to colonize mucosal surfaces, to invade extra-intestinal tissues, to resist the bactericidal effect of complement, to survive and multiply in body fluids with low concentrations of available iron, to escape phagocytosis and intracellular killing by phagocytes, and to induce tissue damage and an inflammatory response by release of cytotoxins or endotoxins. Several virulence attributes, including lipopolysaccharide (e.g. O18) and capsule (e.g. K1) (Pluschke et al., 1983), fimbriae and other surface antigens mediating mannose-resistant haemagglutination (MRHA) (e.g. P, AFA, S, Vir, 31A and F165) (Fairbrother et al., 1986; Girardeau et al., 1988; Hacker, 1989), cytotoxins (e.g. haemolysin, Vir cytotoxin, cytolethal necrosing toxin) (Morris et al., 1982; Korhonen et al., 1985), aerobactin (Carbonetti et al., 1986), ColV and

* Author for correspondence. Tel. (514) 773-8521 ext. 233; fax (514) 773-2161.

Abbreviations: MRHA, mannose-resistant haemagglutination; XP, 5-bromo-4-chloro-3-indolyl phosphate.
Vir plasmids (Morris et al., 1982; Agüero \& Cabello, $1983)$, have been associated with the ability of $E$. coli to cause extra-intestinal infections.

$E$. coli of serogroup $\mathrm{O} 115$ induce septicaemia and polyserositis in calves and piglets (Fairbrother et al., 1986, 1988a, 1989). These strains express a fimbrial antigen complex, F165, consisting of fimbrial components $F 165_{1}$ and $F 165_{2}$, the former demonstrates binding specificity for the Forssman antigen found on sheep erythrocytes (Fairbrother et al., 1986; J. M. Fairbrother and others, unpublished). They possess the pap and $s f a$ operons, which are commonly associated with $E$. coli isolated from extra-intestinal diseases (Harel et al., $1991 a$ ); they also possess the aerobactin system, are resistant to the bactericidal effect of serum, are nonhaemolytic and do not produce verotoxin (Fairbrother $e t$ $a l ., 1988 a$ ). The presence of fimbrial antigen complex F165 and binding to the galactose- $N$-acetyl- $\alpha(1-3)$ galactose- $N$-acetyl moiety have been associated with production of septicaemia in newborn piglets experimentally inoculated with serogroup O115 strains (Fairbrother et al., 1989). However, the role of this fimbrial antigen and its adhesin in the development of disease has not been ascertained.

Transposon mutagenesis has been used to identify virulence determinants in a variety of pathogens. Manoil \& Beckwith (1985) have described a bacterial transposon 
Tn 5 IS $50_{\mathrm{L}}:: p h o A$ (TnphoA), a modified form of Tn5, which carries the $E$. coli alkaline phosphatase structural gene without the natural promoter or signal sequence. After random insertion of TnphoA into genomic DNA, those insertions that yield in-frame fusions between a target gene and pho $A$ encode hybrid proteins that have a carboxy-terminal fragment of PhoA fused to an aminoterminal portion of the target protein product (Manoil \& Beckwith, 1985). These hybrid proteins display alkaline phosphatase activity only if the target gene encodes an extracytoplasmic protein and so provides the requisite signals for transport of the carboxy-terminal phoA gene product into the periplasmic space (Manoil \& Beckwith, 1985). Because most bacterial virulence determinants are expressed at the cell surface, this technique selects for TnphoA insertions into such genes (Taylor et al., 1987, 1989; Finlay et al., 1988; Miller et al., 1989). Thus, using the TnphoA system, isogenic strains of a pathogenic F165-positive strain of $E$. coli of serogroup 0115 were produced, with respect to two putative virulence determinants, mannose-resistant haemagglutination of sheep erythrocytes and production of the F165 fimbrial antigen, in order to evaluate the role of these determinants in the pathogenesis of $E$. coli septicaemia.

\section{Methods}

Bacterial strains and plasmids. Escherichia coli strain 5131 is a wildtype strain (O115: $\left.\mathrm{K}^{-}: \mathrm{H} 51: \mathrm{F} 165\right)$ isolated from the intestinal contents of a diarrhoeic piglet. Strain 5131 haemagglutinates sheep erythrocytes but not bovine erythrocytes, produces aerobactin, produces Colicin V, and is serum resistant. Strain 5131 was found to have sequences related to the pap and sfa operons (Harel et al., 1991a). E. coli strain SM10 possessing plasmid pRT733 carrying TnphoA was used for transposon mutagenesis (Taylor et al., 1989). Plasmids pCJ7 (Harel et al., 1992) and pANN801-13 (Hacker et al., 1985) were used as the source of DNA probes for fimbrial genes coding for $\mathrm{F} 65_{1}$, a Prs-like fimbriae, and for $\mathrm{S}$ fimbriae, respectively. Bacteria were cultivated in L-broth or on $\mathrm{L}$ agar plates containing $1.5 \%$ (w/v) agar (Miller, 1972). F165-positive strains were grown on minimal medium (MD-1) for the maximal expression of F165 fimbrial antigen (Fairbrother et al., 1988b).

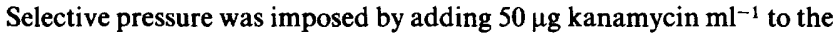
medium.

Mutagenesis. Mutations were induced by random insertion of the TnphoA sequence into chromosomal or plasmid DNA of $E$. coli strain 5131. The mutagenesis was accomplished by using the plasmid pRT733 which carries the TnphoA insertion in donor $E$. coli strain SM10 ( $\lambda$ pir) (Taylor et al., 1989; Miller \& Mekalanos, 1988). pRT733 is a suicide vector since it cannot replicate in the absence of the protein encoded by the $\lambda$ pir transducing phage, but it can be mobilized from strain SM10 ( $\lambda$ pir) into strain 5131 during mating. Fresh colonies of donor strain SM10 carrying the vector pRT733 were mated with recipient strain $5131\left(\mathrm{Sm}^{\mathrm{r}} \mathrm{Ap} \mathrm{p}^{\mathrm{r}}\right)$ in LB plates and then incubated at $37^{\circ} \mathrm{C}$ for $16 \mathrm{~h}$. After dilution, the mating mix was then spread onto agar containing streptomycin and kanamycin. Therefore, selection for $\mathrm{Km}^{\mathrm{r}}$ and $\mathrm{Sm}^{\mathrm{r}}$ resulted in the transposition of TnphoA into the chromosome or plasmid of the $\mathrm{Sm}^{\mathrm{r}}$ recipient. The indicator XP (5-bromo-4-chloro-3indolyl phosphate) was included in the agar to detect those transposi- tions that resulted in active phoA gene fusions in the recipient. Of

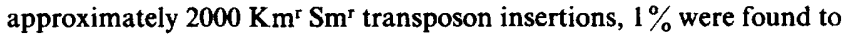
produce blue colonies on agar in the presence of alkaline phosphatase substrate XP.

DNA manipulation techniques. Chromosomal DNA was isolated according to the method of Marmur (1961). The method of Birnboim \& Doly (1979) was followed for the isolation of plasmid DNA. Plasmid DNA was extracted and purified by ultracentrifugation in caesium chloride/ethidium bromide gradients (Maniatis et al., 1982). DNA was digested with the appropriate restriction endonucleases under conditions specified by the manufacturer (Pharmacia-LKB). Electrophoretic analysis of DNA was done using $0.7 \%$ agarose gel and Tris/borate buffer (0.045 M-Tris/borate, 0.001 M-EDTA) (Maniatis et al., 1982). Restriction fragments of plasmid DNA were purified by extraction from low-gelling-temperature agarose after electrophoresis (Harel et al., $1991 b$ ).

Southern hybridization, gene probes and radioactive labelling. The transfer of DNA fragments from agarose gels to nitrocellulose filters, washing and autoradiography were done as described by Southern (1975). Stringent conditions were used for the washing procedure. The filters were washed in $2 \times \operatorname{SSC}(1 \times \operatorname{SSC}$ is $0.15 \mathrm{M}-\mathrm{NaCl}+0.015 \mathrm{M}-$ sodium citrate) twice for $5 \mathrm{~min}$ at room temperature each time, then in $2 \times$ SSC with $0.5 \%$ SDS twice for 30 min each time at $65^{\circ} \mathrm{C}$, and finally in $0.1 \times \mathrm{SSC}$ twice for $5 \mathrm{~min}$ each time at room temperature. Fimbrial probes representing the full $F 165_{1}$ operon (BamHI fragment from pCJ7, encoding the $F 165_{1}$ operon) (Harel et al., 1992) and $s f a$ operon (EcoRV fragment from pANN801-13) (Hacker et al., 1985) were used in this study. Appropriate DNA fragments were cut from the gel, purified, and radiolabelled with $\left[\alpha^{-32}\right.$ P]dCTP using an oligonucleotide random priming labelling kit (Pharmacia-LKB) according to the manufacturer's instructions (Harel et al., 1991 b).

Enzyme activity. To measure the amount of alkaline phosphatase produced by the gene-fusion-carrying strains, bacteria were grown in medium for $16 \mathrm{~h}$. Cells were harvested and suspended in $1 \mathrm{M}$-Tris $/ \mathrm{HCl}$ (pH 8.0), a sample was diluted $1 / 20$ and permeabilized with SDS and chloroform. The alkaline phosphatase activity was expressed in enzyme units per $\mathrm{OD}_{660}$ unit (Miller, 1972; Taylor et al., 1989).

Detection of F165 fimbrial antigen. Production of F165 antigen by bacteria grown on MD-1 agar was determined using an immunodot technique (Contrepois et al., 1989).

Isolation of fimbriae, SDS-PAGE and immunoblotttng. Crude fimbrial extracts were prepared from bacteria grown on MD-1 plates as described previously (Fairbrother et al., 1988b). After treatment of the fimbrial samples by boiling for $5 \mathrm{~min}$ in $10 \mathrm{~mm}$-Tris/ $\mathrm{HCl}(\mathrm{pH} 7.8)$ containing $4 \%(\mathrm{w} / \mathrm{v})$ SDS, $0.01 \mathrm{ml} 2$-mercaptoethanol, $0.2 \mathrm{ml}$ glycerol and $0.002 \%$ bromophenol blue, the samples were run on slab gels as described previously (Fairbrother et al., 1988b). Western blotting (immunoblotting) was done by the method of Towbin et al. (1979). Crude fimbrial extracts from wild-type $E$. coli strain 5131 and from TnphoA mutants were electrophoresed in the presence of SDS $(0.1 \%$, $\mathrm{w} / \mathrm{v})$ on $15 \%(\mathrm{w} / \mathrm{v})$ polyacrylamide gels. Following electrotransfer to nitrocellulose, the filters were reacted with anti-F165 and anti-PhoA sera to identify the fimbrial bands and pho $A$ gene fusion products, respectively.

Gels were electroblotted for $16 \mathrm{~h}$ at $30 \mathrm{~V}$ on nitrocellulose using cold electroblotting buffer in $20 \%(\mathrm{v} / \mathrm{v})$ methanol containing $25 \mathrm{~mm}$-Tris and $192 \mathrm{~mm}$-glycine. The filters were saturated with $5 \%(\mathrm{w} / \mathrm{v})$ skim milk and incubated for $90 \mathrm{~min}$ at $25^{\circ} \mathrm{C}$ with anti-F165 or anti-PhoA serum in Tris-buffered saline (TBS; $20 \mathrm{mM}$-Tris/HCl, pH 7.5, $500 \mathrm{mM}$ $\mathrm{NaCl}$ ) containing $0.05 \%(\mathrm{v} / \mathrm{v})$ Tween 20 (TTBS), plus $2.5 \%(\mathrm{w} / \mathrm{v})$ skim milk. Filters were then incubated for $1 \mathrm{~h}$ at $25^{\circ} \mathrm{C}$ in a $1 / 5000$ dilution of biotinylated goat anti-rabbit immunoglobulin $\mathrm{G}$. After a short wash in 
TTBS, the filters were incubated in a $1 / 3000$ dilution of peroxidaselabelled avidine. Finally, filters were washed twice in TTBS and twice in TBS and reacted with hydrogen peroxide substrate and 4chloronaphthol chromogen.

Polyclonal antibodies were generated against FPLC-purified F165 antigen complex from the F165-antigen-producing $E$. coli strain 4787 and against alkaline phosphatase by injection of $10 \mu \mathrm{g}$ aliquots of purified proteins into rabbits as described previously (Fairbrother $e t$ $a l .$, 1986). To enhance the specificity of immunodetection of hybrid proteins, the anti-F165 and anti-PhoA antibodies were absorbed against whole cells of strain 4787 grown at $18^{\circ} \mathrm{C}$ or of strain CC118 ( $\triangle p h o A$ ), respectively (Manoil \& Beckwith, 1985; Coulton et al., 1988).

Immunoelectron microscopy. Drops of a washed bacterial suspension were placed on Formvar-coated grids for $3 \mathrm{~min}$. The grids were then placed sequentially on drops of phosphate-buffered saline, $\mathrm{pH} 7 \cdot 4$ (PBS; 0.2 M- $\mathrm{NaH}_{2} \mathrm{PO}_{4}, 0.2 \mathrm{M}-\mathrm{Na}_{2} \mathrm{HPO}_{4}, 0.1 \mathrm{M}-\mathrm{NaCl}$ ) with $1 \%(\mathrm{w} / \mathrm{v})$ ovalbumin for $5 \mathrm{~min}$ and a suitable dilution of rabbit anti-F165 serum for $30 \mathrm{~min}$. Grids were washed and placed on drops of colloidal gold particles $(5 \mathrm{~nm}$ ) conjugated to protein A (Sigma) for $30 \mathrm{~min}$. After a final washing step, the grids were stained with $1 \%(\mathrm{w} / \mathrm{v})$ phosphotungstic acid (pH 7.0) and examined with an electron microscope (Philips 201) at an accelerating voltage of $60 \mathrm{kV}$ (Broes et al., 1988).

Detection of F165 adhesin. The presence of F165 adhesin was determined by a haemagglutination assay using sheep erythrocytes with $2 \%(\mathrm{w} / \mathrm{v})$ mannose as described previously (Fairbrother et al., 1986).

Hydrophobicity. The hydrophobicity of bacterial cells was determined by the method of Lindahl et al. (1981). Hydrophobicity values are reported as the molar concentrations of $\left(\mathrm{NH}_{4}\right)_{2} \mathrm{SO}_{4}$ required to cause autoagglutination of the bacterial suspensions.

Serum bactericidal assay. Bacterial survival in serum was examined using a bactericidal assay adapted from Taylor \& Kroll (1983). Briefly, a 10-fold dilution of overnight culture was resuspended in TBS and incubated under agitation for $1.5 \mathrm{~h}$. A $10 \mu \mathrm{l}$ volume of this culture was resuspended in $990 \mu \mathrm{l}$ gelatin/Veronal-buffered saline plus magnesium and calcium ions (pH 7.35) $\left(\mathrm{GVB}^{2+}\right)$ (Taylor \& Kroll, 1983), to obtain approximately $10^{7}$ c.f.u. $\mathrm{ml}^{-1}$. A $100 \mu$ l volume of this suspension was added to $900 \mu \mathrm{l}$ normal rabbit serum. After mixing, the bacterial suspensions were incubated at $37^{\circ} \mathrm{C}$ for $3 \mathrm{~h}$. Viable counts were estimated at hourly intervals by plating $100 \mu$ of the mixture on brain heart infusion agar plates (Difco). Strains demonstrating a viable count of $>100 \%$ of the inoculum after $3 \mathrm{~h}$ were considered to be resistant to serum; strains demonstrating a viable count of $<100 \%$ but $>1 \%$ of the inoculum were considered to have intermediate sensitivity to serum; and strains demonstrating a viable count of $<1 \%$ of the inoculum were considered to be sensitive to serum.

Lethality test. An overnight tryptic soy broth (Difco) culture was centrifuged and resuspended in PBS. A $0.5 \mathrm{ml}$ volume of this suspension was inoculated subcutaneously into $1 \mathrm{~d}$-old chickens obtained from a local hatchery. The $50 \%$ lethal dose $\left(\mathrm{LD}_{50}\right)$ of each strain was determined by inoculating groups of five chickens with doses of bacteria between $10^{8}$ to $10^{6}$ c.f.u. $\mathrm{ml}^{-1}$ in 2-fold dilution steps. Bacterial counts were estimated using a spread plate method on brain heart infusion agar (Difco). Chickens were observed for $2 \mathrm{~d}$, mortalities were recorded and the $50 \%$ lethal dose $\left(\mathrm{LD}_{50}\right)$ was calculated (Reed \& Muench, 1938).

\section{Results}

\section{Isolation and characterization of TnphoA gene lusions}

After random insertion of TnphoA into the genome of F165-antigen-positive $E$. coli strain 5131 , colonies were screened for in-frame TnphoA insertions in genes encoding exported proteins on LB agar containing XP. Of $2000 \mathrm{Km}^{\mathrm{r}} \mathrm{Sm}^{\mathrm{r}}$ transposon insertion mutants, $1 \%$ were found to produce blue colonies in the presence of alkaline phosphatase XP substrate. Mutants were screened for loss of the haemagglutination phenotype using sheep

Table 1. Characteristics and virulence in chickens of TnphoA mutants of E. coli strain 5131

The results for MRHA, presence of F165 antigen, hydrophobicity, serum sensitivity and $\mathrm{LD}_{50}$ are representative of averages obtained from triplicate assays.

\begin{tabular}{|c|c|c|c|c|c|c|c|}
\hline & $\begin{array}{c}\text { Mutant } \\
\text { no. }\end{array}$ & MRHA* & $\begin{array}{l}\text { F165 } \\
\text { anti- } \\
\text { gent }\end{array}$ & $\begin{array}{l}\text { Hydro- } \\
\text { phobicity } \\
\text { value }(M)_{\ddagger}^{\ddagger}\end{array}$ & $\begin{array}{l}\text { Survival in } \\
\text { serum }(\%) \S\end{array}$ & $\begin{array}{c}\log _{10} \\
L_{50}\end{array}$ & Virulence \\
\hline $\begin{array}{l}\text { Wild-type } \\
\text { Mutants } \\
\qquad \text { Class I }\end{array}$ & $\begin{array}{l}5131 \\
\text { M9 } \\
\text { M43 } \\
\text { M48 } \\
15\end{array}$ & $\begin{array}{l}+ \\
- \\
- \\
-\end{array}$ & $\begin{array}{l}+ \\
- \\
- \\
+1-\end{array}$ & $\begin{array}{r}0 \cdot 125 \\
4 \\
2 \\
2 \\
4\end{array}$ & $\begin{array}{r}227 \\
117 \\
125 \\
138 \\
10\end{array}$ & $\begin{array}{l}6 \cdot 8 \\
6 \cdot 8 \\
6 \cdot 8 \\
6 \cdot 7 \\
7 \cdot 2 \\
7\end{array}$ & $\begin{array}{c}\text { Virulent } \\
\text { Virulent } \\
\text { Virulent } \\
\text { Virulent } \\
\text { Intermediate }\end{array}$ \\
\hline Class II & $\begin{array}{r}6 \\
9 \\
17 \\
18 \\
2\end{array}$ & $\begin{array}{l}- \\
- \\
- \\
+ \\
+\end{array}$ & $\begin{array}{l}+ \\
+ \\
+ \\
+ \\
+\end{array}$ & $\begin{array}{l}\text { ND } \\
0 \cdot 25 \\
0.5 \\
\text { ND } \\
0.5\end{array}$ & $\begin{array}{c}4 \cdot 7 \\
29 \\
5 \cdot 8 \\
1 \cdot 2 \\
0.8\end{array}$ & $\begin{array}{l}7 \cdot 3 \\
7 \cdot 9 \\
7 \cdot 8 \\
7 \cdot 2 \\
8 \cdot 9\end{array}$ & $\begin{array}{c}\text { Intermediate } \\
\text { Intermediate } \\
\text { Intermediate } \\
\text { Intermediate } \\
\text { Avirulent }\end{array}$ \\
\hline
\end{tabular}

* $\mathrm{MRHA}^{-}$, no haemagglutination activity; $\mathrm{MRHA}^{+}$, haemagglutination activity.

+ As tested by immunodot. + , strongly positive; $+/-$, weakly positive; - , negative.

$\ddagger$ Molar concentration of $\left(\mathrm{NH}_{4}\right)_{2} \mathrm{SO}_{4}$ required to cause autoagglutination of bacterial suspensions. ND, Not determined.

$\S$ Bacteria $\left(10^{6}\right.$ c.f.u. $\left.\mathrm{ml}^{-1}\right)$ in the late exponential growth phase were incubated in the presence of $90 \%(\mathrm{v} / \mathrm{v})$ fresh rabbit serum, after growth in MD-1 medium. Results are expressed as the percentage of initial inoculum of each strain after $3 \mathrm{~h}$ incubation.

II Chickens (1-d-old) were injected subcutaneously with different dilutions of bacteria. 


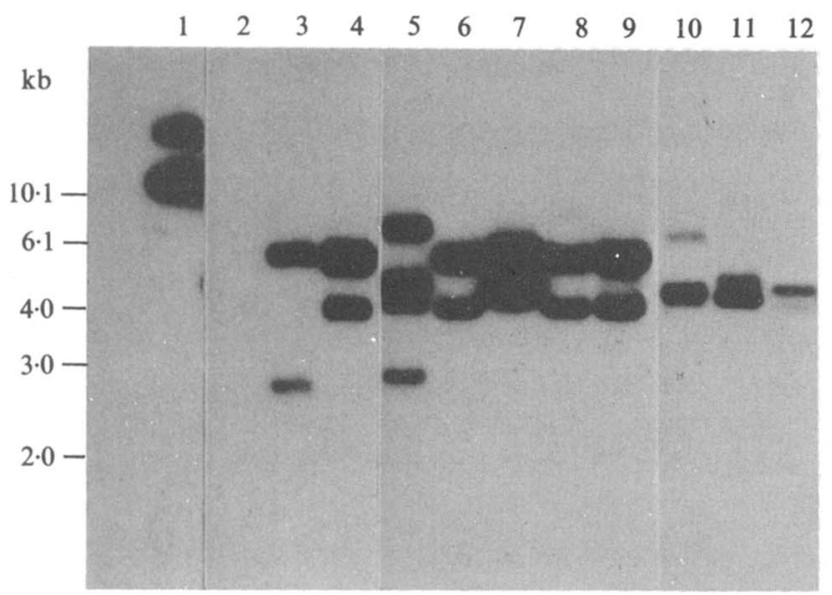

Fig. 1

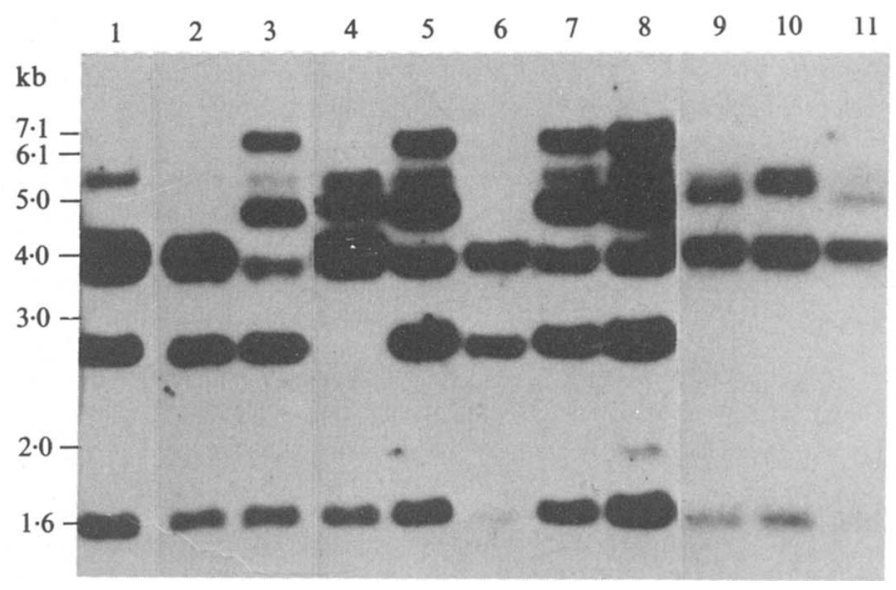

Fig. 2

Fig. 1. Southern blot analysis of genomic DNA from 10 mutant strains digested with BamHI/EcoRV. The probe was a $1.9 \mathrm{~kb} H$ indIII$B a m H I$ TnphoA-derived fragment that in $B a m H I / E c o R V$ double digests hybridizes to the upstream fragment (relative to transcription of the fusion) more strongly than to the downstream fragment. Lane 1, pRT733 (carrying TnphoA); lane 2, wild-type strain 5131; lane 3, mutant 2 (serum sensitive); lane 4, mutant $6\left(\mathrm{MRHA}^{-} \mathrm{F} 165^{+}\right)$; lane 5, mutant $15\left(\mathrm{MRHA}^{-} \mathrm{F} 165^{+/-}\right)$; lane 6, mutant $9\left(\mathrm{MRHA}^{-} \mathrm{F}^{2} 65^{+}\right)$; lane 7, mutant 18 (intermediate serum resistance); lane 8, mutant 19 (MRHA-F165'); lane 9, mutant 29 (MRHA-F165'); lane 10, mutant M9 (MRHA-F165'); lane 11, mutant M43 (MRHA-F165'); lane 12, mutant M48 (MRHA-F165').

Fig. 2. Southern blot analysis of genomic DNA from 10 mutant strains digested with BamHI/EcoRV. The probe was a $9 \mathrm{~kb}$ BamHI fragment derived from plasmid pCJ7, a prs-like operon, coding for $\mathrm{F} 165_{1}$. Lane 1, wild-type strain 5131; lane 2, mutant 2 (serum

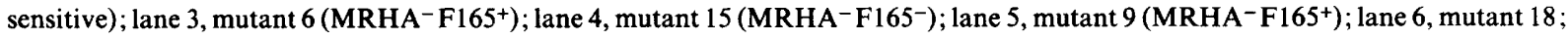
lane 7, mutant 19 (MRHA $^{-}$F165 $5^{+}$); lane 8, mutant 29 (MRHA-F165'); lane 9, mutant M9 (MRHA-F165-); lane 10, mutant M43

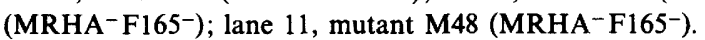

erythrocytes, F165 antigen production using immunodot assay with anti-F165 serum, and serum sensitivity using the serum bactericidal assay. At least two distinct classes of alkaline-phosphatase-secreting mutants were observed with respect to haemagglutination and F165 antigen production (Table 1): class I (mutants M9, M43, M48, 15), F165- MRHA $^{-}$, serum resistant (except mutant 15); class II (mutants 6, 9, 17, 19, 29), F165 MRHA $^{-}$, intermediate serum sensitivity. Mutants 19 and 29 were class II mutants not shown in Table 1, but had properties similar to that of mutant 6 . Mutant 18 was $\mathrm{F} 165^{+} \mathrm{MRHA}^{+}$, and of intermediate serum sensitivity. Mutant 2 was $\mathrm{F} 165^{+} \mathrm{MRHA}^{+}$, serum sensitive and avirulent.

\section{Mapping of TnphoA insertions}

As restriction endonuclease $E c o \mathrm{RV}$ does not cut within transposon TnphoA, Southern hybridization of EcoRVdigested chromosomal DNA probed with an internal HindIII fragment of TnphoA was performed for each of the mutant strains (data not shown). This analysis verified that only single TnphoA insertions were present in most of the tested mutant strains. Moreover, single TnphoA insertions were present in distinct EcoRV fragments ranging from 9 to $20 \mathrm{~kb}$ [including the inserted
TnphoA(7.6 kb)]. One MRHA-F165- mutant, mutant 15 , possessed two $E c o$ RV fragments which hybridized with the TnphoA DNA probe indicating the presence of a cointegrate or a double insertion of TnphoA.

Mutants were characterized with respect to the chromosomal DNA digestion patterns obtained with BamHI, which cuts once in TnphoA (data not shown), and with BamHI and EcoRV (Fig. 1). The DNA probe was a $1.9 \mathrm{~kb}$ HindIII-BamHI TnphoA-derived fragment that with $B a m \mathrm{HI} / E c o \mathrm{RV}$ double digests will hybridize to the upstream fragment (relative to transcription of the gene fusion) more strongly than to the downstream fragment (Taylor et al., 1988). After chromosomal DNA double digests with $B a m \mathrm{HI} / E c o \mathrm{RV}$, the class I MRHA-F165- mutants M9, M43, and M48 (Fig. 1, lanes 10,11 , and 12 , respectively) presented a distinct hybridization pattern with an upstream band of 5-4 kb and a downstream band of 4-7 kb. The class I MRHA-F165- mutant, mutant 15 (Fig. 1, lane 5), revealed four hybridizing bands, due to a double Tnpho $A$ insertion or to a cointegrate structure. Class II MRHA- $^{-} \mathrm{F} 65^{+}$mutants demonstrated a hybridization pattern with an upstream band of $5-5.8 \mathrm{~kb}$ and a downstream band of $4-4.5 \mathrm{~kb}$ (Fig. 1, lanes 4, 6, 8, 9). The serum-sensitive mutant 2 had a $6 \mathrm{~kb}$ upstream band and a $2.8 \mathrm{~kb}$ downstream band (Fig. 1, lane 3 ). 
Table 2. Regulation of expression of TnphoA gene fusions in E. coli strain 5131 by environmental modulation

\begin{tabular}{|c|c|c|c|c|c|c|c|}
\hline \multirow{2}{*}{\multicolumn{2}{|c|}{$\begin{array}{l}\text { Strain or } \\
\text { mutant* }\end{array}$}} & \multicolumn{6}{|c|}{ Alkaline phosphatase activity } \\
\hline & & $\begin{array}{c}\mathrm{MD}-1 \\
37^{\circ} \mathrm{C} / 18^{\circ} \mathrm{C}\end{array}$ & $\begin{array}{c}\text { Ratio of PhoA } \\
\text { activity at } \\
37^{\circ} \mathrm{C} / 18^{\circ} \mathrm{C}\end{array}$ & $\begin{array}{c}\text { MD-1 + } \\
5 \text { mM- } \\
\text { alanine }\end{array}$ & $\begin{array}{l}\text { Ratio of PhoA } \\
\text { activity of cells } \\
\text { grown on } \\
\text { MD-1/MD-1 } \\
+ \text { alanine }\end{array}$ & $\begin{array}{l}\text { MD-1 }+ \\
10 \text { g glucose } \mathrm{I}^{-1}\end{array}$ & $\begin{array}{l}\text { Ratio of PhoA } \\
\text { activity of cells } \\
\text { grown on } \\
\text { MD-1/MD-1 } \\
\text { + glucose }\end{array}$ \\
\hline \multirow{5}{*}{ Class I } & 5131 & $0.18 / 0.54$ & $0 \cdot 3$ & 0.4 & 0.45 & $0 \cdot 18$ & 1.0 \\
\hline & (M9 (MRHA-F165-) & $40 \cdot 31 / 4 \cdot 82$ & $8 \cdot 36$ & $17 \cdot 2$ & $2 \cdot 3$ & $29 \cdot 1$ & 1.4 \\
\hline & M43 (MRHA-F165') & $28 \cdot 09 / 9 \cdot 11$ & 3.95 & $10 \cdot 5$ & $2 \cdot 7$ & $12 \cdot 9$ & $2 \cdot 2$ \\
\hline & M48 (MRHA-F165') & $25 \cdot 82 / 4 \cdot 39$ & $5 \cdot 88$ & $14 \cdot 1$ & 1.8 & $10 \cdot 1$ & $2 \cdot 6$ \\
\hline & $15\left(\mathrm{MRHA}^{-} \mathrm{F} 165^{+/-}\right)$ & $20 \cdot 9 / 0 \cdot 7$ & $29 \cdot 9$ & $11 \cdot 1$ & 1.9 & 6.7 & $3 \cdot 1$ \\
\hline \multirow{3}{*}{ Class II } & (6 (MRHA-F165') & $10 \cdot 6 / 1 \cdot 0$ & $5 \cdot 3$ & $5 \cdot 5$ & 1.9 & $3 \cdot 16$ & $3 \cdot 4$ \\
\hline & 9 (MRHA-F165+) $^{-}$ & $10 \cdot 9 / 1 \cdot 3$ & 8.4 & $5 \cdot 9$ & 1.8 & $6 \cdot 2$ & 1.75 \\
\hline & $17\left(\mathrm{MRHA}^{-} \mathrm{F} 165^{+}\right)$ & $10 \cdot 1 / 2 \cdot 4$ & $4 \cdot 2$ & 4.8 & $2 \cdot 1$ & $4 \cdot 1$ & $2 \cdot 4$ \\
\hline
\end{tabular}

* MRHA-F165-, no haemagglutination activity, negative as tested by immunodot with anti-F165 serum; $\mathrm{MRHA}^{-} \mathrm{F}^{-} 65^{+}$, no haemagglutination activity, positive as tested by immunodot with anti-F165 serum.

Although most mutants had a plasmid profile similar to that of wild-type strain 5131 , mutant 18 showed a different plasmid profile. Moreover, hybridization with the TnphoA probe of a gel containing plasmid preparations of each of the mutants revealed that mutant 18 contained a high molecular mass plasmid which reacted with the probe (data not shown). Thus, only mutant 18 ( $\mathrm{MRHA}^{+} \mathrm{F} 165^{+}$, intermediate serum sensitivity) had a TnphoA mutation within one of the large plasmids harboured by strain 5131 .

E. coli strain 5131 was shown previously to be genotypically positive for $\mathrm{P}$ and $\mathrm{S}$ probes (Harel et al., 1991a). Southern blotting of EcoRV/BamHI-digested chromosomal DNA from $E$. coli strain 5131 and the class I and class II mutants was done using probes representing the full $F 165_{1}$ operon (BamHI fragment from pCJ7, encoding the F165 1 operon) (Harel et al., 1992) and the sfa operon (EcoRV fragment from pANN801-13) (Hacker et al., 1985). The $F 165_{1}$ operon shows a BamHI/EcoRV restriction map similar to the prs and pap-2 clones (Lund et al., 1988; Karr et al., 1989; Harel et al., 1992). Therefore, the disappearance of specific bands could be mapped in the F165 mutants. The blots demonstrated that TnphoA insertions in the class I and class II mutants were in the $F 165_{1}$ operon, since the distribution of some bands hybridizing to the F165, probe had changed with respect to those of strain 5131 (Fig. 2). Moreover, the disappearance of F165 specific bands and the pattern of bands corresponding to the $F 165_{1}$ sequences adjacent to TnphoA indicated that Tnpho $A$ insertions in class I strains were within the $5^{\prime}$ end region (genes $A H C$ ) of the $F 165_{1}$ operon but were different insertions (Fig. 2, lanes 4, 9, 10, 11). TnphoA insertions in class II mutants are within the $3^{\prime}$ end region hybridizing with the $F 165_{1}$ operon (Fig. 2, lanes 3, 5, 7, 8). For most class I MRHA-F165- mutants, TnphoA insertions were clustered within a region of $3 \mathrm{~kb}$, whereas class II MRHA- mutants contained TnphoA insertions clustered within a region of $1.0 \mathrm{~kb}$ (Fig. 1). None of the TnphoA insertions were in the $s f a$-related sequences, since the mutants showed hybridization patterns with the $s f a$ operon probe from pANN801-3 similar to that of the strain 5131 (data not shown).

\section{Analysis of PhoA fusion products}

The PhoA fusion products of the mutants were characterized by Western blotting using rabbit anti-alkaline phosphatase serum. The PhoA fusion products were similar in size or larger than alkaline phosphatase (data not shown). The sizes of the fusion products ranged from

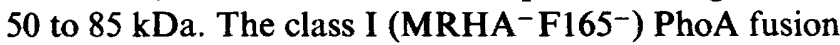
products ranged from 50 to $85 \mathrm{kDa}$; class II (MRHA ${ }^{-}$) PhoA fusion products ranged from 55 to $65 \mathrm{kDa}$.

\section{Alkaline phosphatase activity}

The alkaline phosphatase (PhoA) activities of class I and II mutants grown under different conditions were assayed in permeabilized cells to study the regulation of expression of products of genes in which TnphoA had been inserted (Table 2). Class II mutants demonstrated similar alkaline phosphatase activity when grown on MD-1 medium at $37^{\circ} \mathrm{C}$, whereas class I mutants demonstrated greater PhoA activity than class II mutants. In all class I and II mutants, growth of cultures at $18^{\circ} \mathrm{C}$ resulted in a decrease of PhoA activity of 4- to 


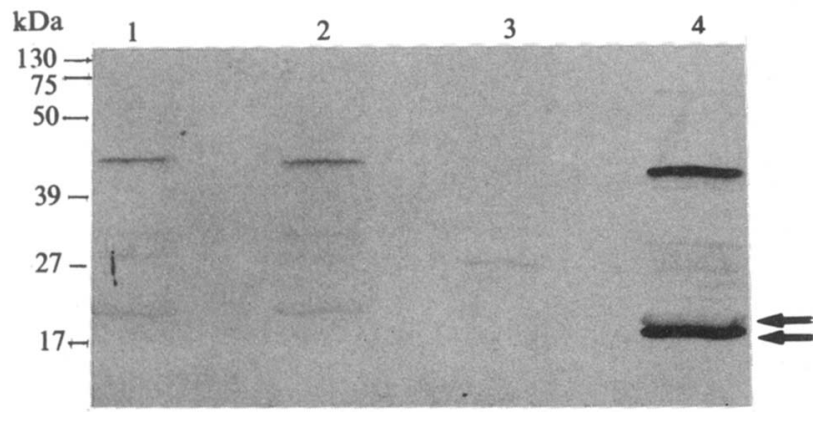

Fig. 3. Western blot of fimbrial preparations from TnphoA insertion mutants. The fimbrial preparations were separated by SDS-PAGE, transferred to nitrocellulose and reacted with rabbit anti-F165 serum. The arrows indicate the 18.5 and $17.5 \mathrm{kDa}$ fimbrial bands. Lane 1 , mutant 6 (MRHA-F165 ${ }^{+}$; lane 2, mutant 9 (MRHA-F165'); lane 3, mutant M9 (MRHA-F165'); lane 4, wild-type 5131. 24-fold. Similarly, addition of $5 \mathrm{~mm}$-alanine or $10 \mathrm{~g}$ glucose $1^{-1}$ to the growth medium resulted in a 2- to 3-fold repression of PhoA activity. Thus, PhoA fusions in class I and class II mutants are modulated by conditions similar to those that affect F165 antigen production.

\section{F165 antigen expression in class I and class II mutants}

Parent strain 5131 grown in MD-1 medium under optimal conditions for F165 fimbrial expression was hydrophobic (hydrophobicity value of $0 \cdot 125 \mathrm{M}$ ) (Table 1 ), demonstrated two fimbrial bands of $18.5 \mathrm{kDa}$ and $17.5 \mathrm{kDa}$ on Western blots using anti-F165 serum and expressed fimbrial structures which were identified as F165 by immunogold-labelling experiments using antiF165 serum (see Fig. $4 a$ ). In contrast, class I (MRHA ${ }^{-}$ F165') mutants were relatively non-hydrophobic (the
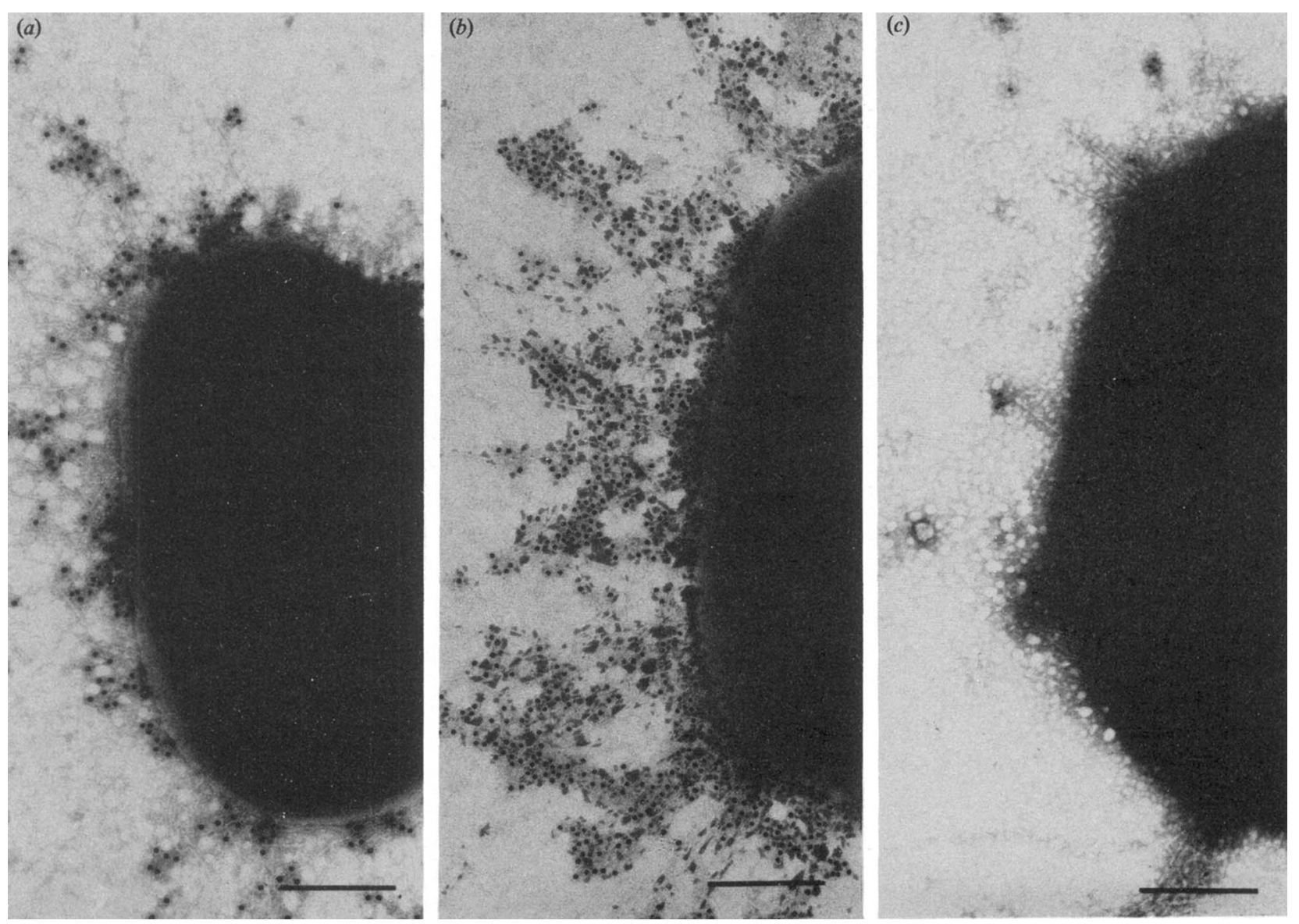

Fig. 4. Electron micrographs after colloidal gold immunolabelling using rabbit anti-F165 serum of (a) E. coli strain 5131, (b) mutant 6 (MRHA-F165') and (c) mutant M9 (MRHA-F165-). Bars, 0.5 $\mu \mathrm{m}$. 
hydrophobicity values ranged from 2-4 M) (Table 1), lacked the $17.5 \mathrm{kDa}$ band and produced little of the $18.5 \mathrm{kDa}$ band (Fig. 3). Moreover, class I mutants expressed very few fimbrial structures on the bacterial surface (Fig. 4c). Class II (MRHA ${ }^{-} \mathrm{F} 165^{+}$) mutants lacked the $17.5 \mathrm{kDa}$ band corresponding to one of the components of F165 fimbrial antigen but still produced the $18.5 \mathrm{kDa}$ band (Fig. 3). These mutants were fimbriate on electron microscopy, in some cases less extensively than strain 5131 (Fig. $4 b$ ), reacted with F165 antiserum using the immunodot technique and demonstrated hydrophobicity values ranging from $0 \cdot 25-1 \mathrm{M}$ (Table 1). Serum-sensitive mutant 2, did not differ from the parent strain with respect to fimbrial characteristics (Table 1).

\section{Virulence of the TnphoA mutants}

Parent strain 5131 was serum-resistant and virulent in 1 d-old chickens, showing a $\log _{10} \mathrm{LD}_{50}$ of $6 \cdot 8$ (Table 1 ). Similarly, most class I MRHA-F165- mutants were serum resistant and virulent in chickens. In contrast, class II MRHA- ${ }^{-} 165^{+}$mutants showed an intermediate sensitivity to serum and were moderately virulent in dayold chickens. Serum-sensitive mutant 2 was avirulent in day-old chickens.

\section{Discussion}

Serogroup O115E. coli strains have been associated with porcine septicaemia and diarrhoea (Fairbrother et al., 1988, 1989). Putative factors important in the pathogenicity of $E$. coli of serotype O115 include fimbrial antigen F165, haemagglutination, lipopolysaccharide, serum resistance, capsule and production of aerobactin (Fairbrother et al., 1986, 1989). TnphoA insertion mutations which define genes involved in or associated with F165 fimbrial production were obtained as $p h o A$ fusions, thus indicating that the target gene encodes a secreted protein.

Like other fimbriae associated with extra-intestinal disease, F165 fimbriae are associated with haemagglutination patterns (Fairbrother et al., 1986; Hacker, 1989), thus reflecting their ability to bind to receptors on the surface of host cells. Strain 5131 expressing the F165 fimbrial antigen recognizes the Forssman antigen of sheep erythrocytes (J. M. Fairbrother and others, unpublished). This property is associated with one of at least two fimbrial components of the F165 antigen complex, designated $\mathrm{F} 165_{1}$, which is encoded by a prslike operon (Harel et al., 1992). The property of adhesion to red blood cells was lost in class I and class II mutants (MRHA ${ }^{-} \mathrm{F}^{165^{+}}$and $\mathrm{MRHA}^{-}{ }^{-}{ }^{165}{ }^{-}$). By analogy to other well characterized fimbrial systems (Hacker, 1989), the adhesion defect of these $E$. coli mutants seems related to $F 165_{1}$ fimbrial adhesin. Strain 5131 expresses at least two fimbrial determinants with structural subunits of $18.5 \mathrm{kDa}$ and $17.5 \mathrm{kDa}$. The mutants of both classes I and II have lost the $17.5 \mathrm{kDa}$ band and the property of MRHA of sheep erythrocytes, which implies that this band is the structural subunit of fimbrial component F165 1 produced by strain 5131. The TnphoA insertions of mutants of class I and class II were located in the $F 165_{1}$ operon, a prs-related operon (Lund et al., 1988; Harel et al., 1991 a). These phoA fusions of class I and class II mutants (MRHA-F165 ${ }^{+}$and MRHA $^{-}$ F165') showed similar environmental regulation to that of F165 as tested in a wild-type strain (Fairbrother $e t$ al., 1988). Complementation and other genetic and biochemical analysis will be necessary to analyse the relationship between the TnphoA insertions and the absence of some components.

It is interesting to note that all class II mutants and mutant 15 , a class I mutant, demonstrated intermediate sensitivity to serum, which correlated with a decrease in virulence in day-old chickens as compared to the parent strain. In contrast, most class I (MRHA- F165-) mutants remained serum resistant, although they did not multiply to as great an extent as the parent strain. The relationship, if any, between serum sensitivity and loss of the haemagglutination phenotype has to be elucidated. It was found that uropathogenic mutant strains that had lost the ability to produce haemolysin and adhesin demonstrated a marked decrease in resistance to normal human serum (Hacker et al., 1988). It was suggested that different virulence factors were organized in functional 'virulence blocks'. Alternatively, in the case of class II mutants, structural modification of the adhesin or the fimbriae might promote binding of $\mathrm{C} 3$ or decrease protection of bacteria from complement-mediated membrane-attack complex.

Initially, the chicken model was used to rapidly screen a large number of mutants for loss of virulence. However, in such a model in which bacteria are introduced directly into the bloodstream, cell-surface structures enabling the bacteria to withstand the effects of complement present in the plasma are more important for bacterial multiplication and development of septicaemia. Bacterial colonization of a mucosal surface or other surface due to fimbrial adhesins would not play an important role in this model. Inoculation of young pigs by a more natural route, the gastro-intestinal tract, will enable us to evaluate more fully the role of the F165 adhesin in the establishment of infection and development of septicaemia.

Strains of enteric bacteria capable of causing bacteraemia and other extra-intestinal infections are often 
significantly resistant to the bactericidal effect of serum (Taylor, 1988). Bacterial serum-resistance is a multifactorial characteristic and involves membrane surface structures which include outer-membrane proteins, lipopolysaccharides and capsular polysaccharides that protect bacteria from the complement-mediated membrane-attack complex. In the present study, TnphoA mutants were found that are highly susceptible to the bactericidal effect of serum. One serum sensitive mutant was avirulent in day-old chickens. Thus, such mutations may give insight into new approaches towards development of attenuated $E$. coli strains useful for vaccine development (Miller et al., 1989).

The authors wish to thank Dr V. Miller (UCLA) for providing the plasmid pRT733, Dr J. Coulton (McGill University) for providing strain CC1 18, and Dr J. Hacker (Wurzburg University) for providing plasmid pANN801-13. We thank Bernadette Foiry (Montreal University) for excellent technical assistance. The work was supported in part by the Ministère de l'Enseignement Supérieur et de la Science of the Government of Québec and by grants to J.H. and J.M.F. from Conseil de Recherches en Sciences Naturelles et en Génie du Canada (OGP0025120 and OGP002294, respectively). J.H. was supported by Fonds de la Recherche en Santé du Québec (870046).

\section{References}

AGÜERo, M. E. \& CABELLo, F. C. (1983). Relative contribution of ColV plasmid and $\mathrm{Kl}$ antigen to the pathogenicity of Escherichia coli. Infection and Immunity 40, 359-368.

Birnboim, H. C. \& Doly, J. (1979). A rapid alkaline extraction procedure for screening recombinant plasmid DNA. Nucleic acids Research 7, 1513-1523.

Broes, A., Fairbrother, J. M., Jacques, M. \& Larivière S. (1988). Isolation and characterization of a new fimbrial antigen (CS1541) from a porcine enterotoxigenic Escherichia coil O8:KX105 strain. FEMS Microbiology Letters 55, 341-348.

Carbonetti, N. H., Boonchai, S., Parry, S. H., Vaisanen-Rhen, V., Korhonen, I. K. \& Williams, P. H. (1986). Aerobactin-mediated iron uptake by Escherichia coli isolates from human extraintestinal infections. Infection and Immunity 51, 966-968.

Contrepois, M., Fairbrother, J. M., KaURa, Y. K. \& Girardeau, J.-P. (1989). Prevalence of CS31A and F165 surface antigens in Escherichia coli isolates from animals in France, Canada, and India. FEMS Microbiology Letters 59, 319-324.

Coulton, J. W., Reid, G. K. \& Campana, A. (1988). Export hybrid proteins FhuA'-LacZ and FhuA'-'PhoA to the cell envelope of Escherichia coli K-12. Journal of Bacteriology 170, 2267-2275.

FaIRBRother, J. M., LARIVIÈRE, S., LALLIER, R. (1986). New fimbrial antigen F165 from Escherichia coli serogroup O115 strains isolated from piglets with diarrhea. Infection and Immunity 51, 10-15.

Fairbrother, J. M., Larivière, S. \& Johnson, W. M. (1988a). Prevalence of fimbrial antigens and enterotoxins in nonclassical serogroups of Escherichia coli isolated from newborn pigs with diarrhea. American Journal of Veterinary Research 49, 1325-1328.

Fairbrother, J. M., Lallier, R., Leblanc, L., Jacques, M. \& LARIVIÈRE, S. (1988b). Production and purification of Escherichia coli fimbrial antigen F165. FEMS Microbiology Letters 56, 247-252.

FaIRBRother, J. M., Broes, A., JACQUES, M. \& LARIVIÈRE, S. (1989). Pathogenicity of Escherichia coli O115:KV165 isolated from pigs with diarrhea. American Journal of Veterinary Research 50, 10291036.
Finlay, B. B, Starnbach, M. N., Francis, C. L., Stocker, B. A., Chatfield, S., Dougan, G. \& Falkow, S. (1988). Identification and characterization of TnphoA mutants of Salmonella which are unable to pass through a polarized MDCK epithelial cell monolayer. Molecular Microbiology 2, 757-766.

Girardeau, J. P., Der Vartanian, M., Ollier, J. L. \& Contrepois, M. (1988). CS31A, a new K88-related fimbrial antigen on bovine enterotoxigenic and septicemic Escherichia coli. Infection and Immunity 56, 2180-2188

HACKER, J. (1989) Genetic determinants coding for fimbriae and adhesins of extra-intestinal Escherichia coli. Current Topics in Microbiology and Immunology, 151, 1-28.

Hacker, J., Schmidt, G., Hughes, C., Knapp, S., Marget, M. \& GOEBEL, W. (1985). Cloning and characterization of genes involved in production of mannose-resistant, neuraminidase-susceptible $(X)$ fimbriae from uropathogenic O6:K15:H31 Escherichia coli. Infection and Immunity 47, 434-440.

HaCker, J., Goebel, W., Hof, H., Konig, W., Konig, B., Scheffer, J., Hughes, C. \& MARRe, R. (1988). Adhesins, serum resistance and cytolysins of $E$. coli-genetic structure and role in pathogenicity. In Bacteria, Complement and the Phagocytic Cell, NATO ASI series H24, pp. 221-229. Edited by F. C. Cabello \& C. Pruzzo. Berlin: SpringerVerlag.

Harel, J., Forget, C., Saint-Amand, J., Daigle, F., Dubreuil, D., JACQUES, M. \& FAIRBROTHER, J. M. (1992). Molecular cloning of a determinant coding for fimbrial antigen $\mathrm{F} 165_{1}$, a Prs-like fimbrial antigen from porcine septicaemic Escherichia coli. Journal of General Microbiology 138, 1495-1502.

harel, J., Daigle, F., Maiti, S., Desautels, C., Labigne, A. \& FAIRBROTHER, J. M. (1991a). Occurence of pap-, sfa-, and afa-related sequences among F165-positive Escherichia coli from diseased animals. FEMS Microbiology Letters 82, 177-182.

Harel, J., Lapointe, H., Fallara, A., LoRTie, L.-A., Bigras-Poulin, M., LARIVIÈre, S. \& Fairbrother, J. M. (1991b). Detection of genes for fimbrial antigens and enterotoxins associated with Escherichia coli serogroups isolated from pigs with diarrhea. Journal of Clinical Microbiology 29, 745-752.

KarR, J. F., Nowicki, B., Truong, L. D., Hull, R. A. \& Hull, S. I. (1989). Purified $P$ fimbriae from two cloned gene clusters of a single pyelonephritogenic strain adhere to unique structures in the human kidney. Infection and Immunity 57, 3594-3600.

Korhonen, T. K., Valtonen, M. V., Parkkinen, J., Vaisanen-Rhen, V., FinNe, J., Ørskov, F., Svenson, S. B. \& Makela, P. H. (1985) Serotypes, hemolysin production, and receptor recognition of Escherichia coli strains associated with neonatal sepsis and meningitis. Infection and Immunity 48, 486-491.

Lindahl, M., FARIS, A., WAdSTRÖM, T. \& HJertén, S. (1981). A new test based on salting out to measure relative hydrophobicity of bacterial cells. Biochimica et Biophysica Acta 677, 471-476.

Lund, B., Marklund, B.-I., Strömberg, N., LindBerg, F., KarlsSON, K.-A. \& NoRmark, S. (1988). Uropathogenic Escherichia coli express serologically identical pili with different receptor binding specificities. Molecular Microbiology 2, 255-263.

Maniatis, T., Fritsch, E. F. \& SambrooK, J. (1982). Molecular Cloning: a Laboratory Manual. Cold Spring Harbor, NY: Cold Spring Harbor Laboratory.

MaNoIL, C. \& BeCKwITH, J. (1985). TnphoA: a transposon probe for protein export signals. Proceedings of the National Academy of Sciences of the United States of America 82, 8129-8133.

MARMUR, J. (1961). A procedure for the isolation of deoxyribonucleic acid from microorganisms. Journal of Molecular Biology 3, 208-218.

Miller, I., Maskell, D., Hormaeche, C., Johnson, K., PiCKard, D. \& DougAN, G. (1989). Isolation of orally attenuated Salmonella typhimurium following TnphoA mutagenesis. Infection and Immunity 57, 2758-2763.

Miller, J. H. (1972). Experiments in Molecular Genetics. Cold Spring Harbor, NY: Cold Spring Harbor Laboratory.

Miller, V. L. \& Mekalanos, J. J. (1988). A novel suicide vector and its use in construction of an insertion mutation: osmoregulation of outer membrane proteins and virulence determinants in Vibrio cholerae requires toxR. Journal of Bacteriology 170, 2575-2583. 
Morris, J. A., Thorns, C. J., ScotT, A. C. \& SoJkA, W. J. (1982). Virulence properties associated with the Vir plasmid : a transmissible pathogenic characteristic associated with strains of invasive Escherichia coli. Journal of General Microbiology 128, 2097-2103.

ØRSKOV, I. \& ØRSKOV, F. (1985). Escherichia coli in extraintestinal infections. Journal of Hygiene 95, 551-575.

Pluschke, G., Mayden, J., Achtman, M. \& Levine, R. P. (1983). Role of the capsule and the $\mathrm{O}$ antigen in resistance of $018: \mathrm{K} 1$ Escherichia coli to complement mediated killing. Infection and Immunity 42, 907913.

ReED, L. J. \& MUENCH, H. (1938). A simple method of estimation for fifty per cent endpoints. American Journal of Hygiene 27, 493-497.

SOUTHERN, E. M. (1975). Detection of specific sequences among DNA fragments separated by gel electrophoresis. Journal of Molecular Biology 98, 503-517.

TAYLOR, P. W. (1988). The mode of C5b-9 attack on susceptible Gramnegative bacteria. In Bacteria, Complement, and the Phagocytic Cell, NATO ASI series H24, pp. 129-138. Edited by C. F. Cabello \& C. Pruzzo. Berlin: Springer-Verlag.
TAYLOR, P. W. \& KRoLl, H. P. (1983). Killing of an encapsulated strain of Escherichia coli by human serum. Infection and Immunity 39, 122-131.

Taylor, R. K., Miller, V. L., Furlong, D. B. \& Mekalanos, J. J. (1987). Use of phoA fusions to identify a pilus colonization factor coordinately regulated with cholera toxin. Proceedings of the National Academy of Sciences of the United States of America 84, 28332837.

Taylor, R. K., Shaw, C., Peterson, K., Spears, P. \& Mekalanos, J. J. (1988). Safe, live Vibrio cholerae vaccines? Vaccine 6, 151-154.

TAYlor, R. K., Manoll, C. \& Mekalanos, J. J. (1989). Broad-hostrange vectors for delivery of TnphoA: use in genetic analysis of secreted determinants of Vibrio cholerae. Journal of Bacteriology 171, $1870-1878$.

Towbin, H., Staehelin, T. \& Gordon, J. (1979). Electrophoretic transfer of proteins from polyacrylamide gels to nitrocellulose sheets: procedure and some applications. Proceedings of the National Academy of Sciences of the United States of America 76, 4350-4354. 